\title{
Philosophical Didactics: How Creativity Can be Compatible with Critical Thinking
}

\author{
Jūratė Baranova \\ Liutauras Degėsys \\ Department of Philosophy, Lithuanian university of educational sciences \\ jurabara@gmail.com
}

\section{Doi:10.5901/mjss.2015.v6n2s5p319}

\begin{abstract}
The modernistic model of upbringing emphasizes more cognitive, instrumental competence, and underlines the importance of critical thinking. The postmodern model of upbringing induces more interdisciplinary and creative thinking. The authors of the article raise the following question: is creativity compatible or incompatible with critical thinking? Relying on their own experience of textbooks writing and implementing in practice, the authors of the article are searching for a concordance between these two seemingly different capacities of the human mind and the two models of upbringing. The article deals with the theoretical, methodological and practical aspects of modern and postmodern philosophical didactics and discerns the practical perspectives of their possible conformity.
\end{abstract}

Keywords: critical thinking, creative thinking, modern didactics, post-modern didactics teaching philosophy

\section{The Investigation of the Problem in Lithuanian Academic Discourse}

In Lithuanian academic discourse, the specifics of the modern and post-modern approach towards didactics without an emphasis on their opposition were discussed by Lilija Duoblienè. In her textbook Contemporary Philosophy of Education: Towards Reflection and Dialogue (2006), Duoblienè analyzes the main paradigms in the contemporary philosophy of education: pragmatist (John Dewey), existential, phenomenological (Maurice Merleau - Pointy), and analytic (Karl R. Popper), which according to our view could be considered as belonging to the modernistic model of upbringing. On the other hand, Duoblienè discusses the features of the post-modern model of upbringing with emphasis on uncertainty in Jean-François Lyotard and Richard Rorty's conceptions. When discussing the methods of upbringing, the researcher interlaces modernist (Hans-Georg Gadamer, Paul Ricouer, Martin Buber) and post-modernist (Jacques Derrida, Robin Usher, Richard Edwards) approaches towards educations without discerning the radical distinction between the two. Such an approach by the author perhaps presupposes that postmodern upbringing could be considered as part of the modernist model of education.

In Duoblienè's monograph Ideological Territories of Educational Change (2011), a consecutive order is also made in turn from the analysis of the modernistic models (pragmatist, constructivist and phenomenological) of education to the creative strategies in education which can be discerned in Michel Foucault's texts. Duoblienè writes: "The postmodernists are linking the problems of education as well as the problems of all other spheres with the usage of language, its manysidedness, playfulness and instability. When the attempt to catch the meaning is made, the meaning is always slipping out. So most of the post-modern insights (e. g. by J. -F. Lyotard, J. Derrida) are linked with the text and self-reflection necessary for its reading, also part of them (e. g. by M. Foucault) - with the other social segments: economy, culture and politics, of course, recognizing the practices of regimes and the relations of power in social life" (Duoblienè, 2011: 90). The author also discusses the possibilities and limitations of the usage of Richard Rorty's vocabulary of ironic language in education. Duoblienè emphasizes not only texts and self-reflection, but also dialogues and metaphors as instruments of post-modern upbringing.

The question thus arises: what could be the relation between the modern and post-modern models of education in teaching philosophy and philosophical ethics? On the other hand, what are the possible theoretical presuppositions on which the features of this relation could be based? What methods could be suggested in the process in philosophy teaching uniting the modern and post-modern approaches? Is the mutual complimentarily of these two approaches possible or at least the discordant harmony of the two? 


\section{On Traditional and Modern Education}

The principles and standards of so called objective or traditional pedagogy are determined by the theoretical preconditions of scientific thinking that emerge from the theoretical reconstruction of the reality by exact sciences. If reality exists as irrespective of our analysis and of ourselves then scrutinizing and analyzing "scientific" glance does not change the reality at the time of investigation and we may see the reality "as it really is". This enables us to look at the reality "objectively" - free of any interest or subjectivity. When a scientist seeks for the truth he eliminates himself as a subject from the process of cognition in favor of objective attitude, the objective truth, in favor of the possibility to see the world what it really is rather what it looks like to him. The principle of "eliminating" the subject may also result from the standard (metaphysical, mechanical) construction of a cognitive subject-object opposition when the subject as though stood in front of an objectively, "naturally" existing reality and because of this position the subject seeks to get the objective knowledge of the reality that opposes him.

This mental construction of "self-renunciation"or desubjectifying the subject is realized into objective, traditional pedagogy when a studying person is declared to be the object, the target of the educational, teaching process. A student must be ready to be "taught", that is to be like a vessel that is being filled in with knowledge. The traditional concept of education is based on the idea of the importance of knowledge: knowledge is declared here to be the greatest and independent value, the objective of the educational process, whereby imperceptibly turning that vessel - a student - of knowledge into an instrument, a means, simply a depository. The exact sciences have refined the tradition of observation of reality turning it into a 'cinematographic' mode of registering reality as a constellation of things. The processes of reality are dissolved by the different sciences into the aggregates of fixed facts which are later one turned into things with the help of a whole lot of constructions, methods, instruments and experiments. Sciences teach us to study, analyze, and describe things on the purpose to get results. Processes then seem to take a backstage position, whereas the goals of human activity are now declared its results, but not the activity nor the process itself.

The knowledge is the equivalent of the material, finite, objective world, so it should be no less material and objective as the world itself, so the knowledge may be, like the things of the reality, be handed over, transferred, transported from the one place to another one. The knowledge is treated and measured as the sufficient amount of information about reality with a purpose to change and transform this reality. Knowledge is understood as a tool or as a tool-kit for operating on reality; knowledge was considered to give the beholder a power to react to reality and get the desirable results. Thus the extracting, categorization, storage and transmission of knowledge became the main worries of education. Such a concept of education was based on a material approach to the world and a mechanical and metaphysical understanding of the world. If the world contains finite and definite amount of things, if the world itself is a comprehensible "thing" then the knowledge one can gain about such a world is as well finite ("definite"): one can understand and know the world in a finite way. If such were the case, through knowledge acquisition and learning one would reproduce the constructions of finite things, recreating the existing and objective structures of things by copying or reconstructing them, making copies of things in the form of knowledge. Although these structures can be very complex, their technical reproduction can be considered as finite, because they hold finite information.

"In the field of education theory, such types of material construction of the world corresponds to the classical disjunction between the subject and object of learning understood as teaching or educating. Here, on the one hand there are "educators" who are the subjects or actors, or "those who" organize the process by setting goals, select the tools, and take the responsibilities for the results; on the other, there are the learners or objects - things, or "those to whom" the process is meant as receivers, that is those who within a given frame or education model are modeled, formed and changed (they are taught). The implications of this disjunction of subject and object of the learning process as applied in this education model are such that the subject ("agent", "actor") is the teacher, the learner therefore becoming an object. This means that as an object of the process, the learner is, a mere passive and indifferent element with no responsibility for the process of education. The teacher as a subject, as the main manager of process of education is responsible for everything. This model does not leave any room for creativity or originality, but this is not all. What is even more, this model implies the denial of individuality, subjectivity and personal commitment for the results and sense of education" (Degèsys 2011: 48).

Many traditional educational systems pretend to declare they are modern. But if the goal of education is the knowledge itself then usually all the "modernity" in education turns into the "modern" methods and principles of categorizing, transmitting, storing, controlling and inspecting knowledge. Contrastingly, in an ever-changing social reality it is not possible to operate with a constant concept of "social thing". Every attempt to simplify, to construct social reality as a thing, as a constant, fails in the face of changing social reality. You may try to make a copy of a thing, but even in the world of things you may be confused by the question of "how many "true" copies may I gain from the one thing?". In 
the world of social processes, can one make a constant copy of permanently changeable reality? The more complex situation is the less sufficient is a simplification or model. The stereotyping of social reality unavoidably leads to or ends up in a mythologizing of social life. If the social life is interactive and reflective it is unavoidable to be interrelated to other agents and actors of social change. The exploring and learning become the permanent interpretation and reinterpretation of social reality, the reflection of what is going on and the assessment of changes that should be relevant to our changeable social reality.

The concept of modern education is based on the assumption that processes of teaching and learning are implemented in everyday life situations, in the ordinary flow of social reality, in every social activity. Social space requires a constant inter-subjectivity, interactivity, a certain formalization and interpretation of the unceasing social relations and ever-changing interpersonal situations. These learning and teaching processes are inseparably integrated into social activity. Due to the permanent change in the social world it is simply impossible and even meaningless to study and learn only about social standards and operate with social constants. A person who is unable to analyze changing current situations and cannot interpret and re-interpret social factors is simply doomed to an unsuccessful socialization. Furthermore, in a social reality subject to constant changes the capacity to re-set oneself into ever-changing social contexts gains a vital significance. The only rational behavior left as a choice is precisely the ability to gather momentum, perceive the signals from the surrounding social reality and, with the help of analysis and interpretation mechanisms, search for the most successful and appropriate ways to respond to those stimuli and change one's (teaching or learning) behavior.

If the education process is understood as an inter-subjective communicative act based upon interpersonal relationships, a process that brings forward the standard questions of social recognition and knowledge then the education should be considered as a possibility of self-comprehension, self-education and self-development. Life is a permanent construction and re-construction, programming and re-programming. Deconstruction is a method of vision and interpretation the world, as well as a way of living. It always implies a certain re-construction with the two meanings of this concept: the re-creation of constructions based on reality and the application of these constructions to the recycling of reality, based on the principles of reality.

\section{On Teaching and Learning of Critical Thinking as Self-teaching and Meta-learning}

The modern education should be considered as a possibility of self-comprehension, self-education and self-development. Life is a permanent construction and re-construction, programming and re-programming. Thus we need new principles and new standards of teaching and learning should that should be based on the modern education program that develops human universality, independent thinking, openness to change and freedom. This educational approach functions as an inseparable possibility to knowledge, understanding and ability. Knowledge grants the possibility to evaluate processes, that is, to raise questions, and look for meaning, and once the person has found it, he/she can form his/her own opinions and attitudes, gain skills, and make rational use of one's abilities. Teachers should be taught by the same procedures we expect them to use in their teaching. If we expect them not only to act, or not only use this "learning by doing", if we expect them encourage students to think, we should encourage the trainers in thinking about thinking. We should stress the importance of mental, cognitive acts, but we should stress the importance of meta-cognitive acts (Knowing about knowing of others, remembering that others remember, and so on), and the importance of meta-affective acts (such as willing to love, desiring to desire). If we want teachers to improve their reasoning skills we should encourage them to reason about how they reason, what are the techniques and technologies of improving the reasoning processes. They need the theoretical analysis of phenomena of education that is based on the philosophical works not only by Plato, Jan Amos Comensky, John Dewey, but also by Henry Bergson, Karl R. Popper, Peter L. Berger and Thomas Luckman also on ideas of philosophy of education by Matthew Lipman and Ivan Illich. Principles and concepts of theoretical analysis of basic principles of philosophy such as objectivity, determinism, expedience, distance, theory and metha-theory should be structured and explained in their relationship to the principles of education. The process of education itself should be revealed and explained by the very principles of social communication: as the process of permanent interpretation and reinterpretation of social reality, the reflection of what is going on and assessment of changes that should be relevant to the changeable social reality. Thus in the process of education the teaching and learning is transforming themselves into selfteaching and meta-learning. The process of education should be analyzed as a whole set of very effective and modern methods and principles of education, such as the methods of mental experiment, self-analysis and self-reflection, logical alternative calculation, logical analysis and critical thinking and should be based on such thinking and ethical strategies as empathy, de-centering from the self and moral imagination. "The self-learning teacher should know how to teach himself and apart the professional competencies he needs very general competencies - competences of critical 
thinking" (Degèsys 2011: 52). It becomes very important to develop the possibility to raise questions and doubts, and not the necessity to find and provide univocal answers. This possibility can be realized through a meta-relationship - one's own relationship with oneself and with others. Evidently, these assumptions presuppose permanent, inevitable reflection and a meta-relationship with oneself. When reflecting, the individual observes him/herself as the object under analysis and then he/she determines what he/she could and would like to do with him/herself and by him/herself.

In the classical situation of education where there is one educator and others are learners, there is a prevailing passive attitude of observance. One can easily imagine a certain state of expectancy, as the learner passively lets him/herself "be taught, educated". He/she transfers all the competences of the subject to the "real" educator, a kind of demiurge, organizer or planner. This passive state does not require any subjectivity, responsibility or initiative. In the classical conception of the education process, the responsibility is simply passed on to the one who takes it in order to get out of the learner an expected social product. In the classical conception of the education there seems to be no question about the personalization of the education process: in the objective process of objective knowledge transference knowledge is considered a thing to be transmitted from a material collection of knowledge pieces into the no less material head of the learner who is ready to receive it.

Modern education is inevitably based on the competence for independent thinking. Self-correction and selfeducation need an ability to decide independently, the ability to test their own theories and verify assumptions, falsify own attitudes and ideas. This is the reason why in the teaching and learning process a specially introduced, visible, controlled and intentional distance is so important: how helpful it is to understand the importance of a meta-theory. A constant analysis and control of the educational situation is inevitable. The education process offers the possibility of continual reflection of the situation under analysis with the introduction of a constant complimentary point of meta-analysis, when one not only observes and discusses what and how it is going on, but also raises the question about the meaning of this specific situation, and about the meaning of the analysis of this question, about the effectiveness of the methods and methodologies used.

Of a great importance in modern education are "unpractical", meta-practical, theoretical, especially metatheoretical disciplines, that provide not only with specific, "pedagogical" knowledge, but also turn the subject of learning towards itself, disciplines that teach not only knowledge, but teach the ways of acquiring new knowledge, teach, how to learn discipline and how to teach oneself. "Whatever the theory, it must be one based on the concept of self-possession, it has to consist of a self-development principle and as any theory, and it has to contain methods, a methodology, an organizational structure, criteria and principles of analysis of their effectiveness, all of which should match this original principle of self-education" (Degèsys 2011: 57).

\section{The Presumptions of Creative Thinking in the Post-modern Philosophical Upbringing}

When modern didactics requests methods based on logical analysis and critical and creative thinking, the post-modern didactics enlarges the limits of the intellectual creative imagination and opens up the possibility for poly-semantic, deconstructing and rhizomatic aspects in thinking. These aspects train the flexibility and inventiveness of thinking and the openness to unexpectedness and experiment, and afford the capacities for orientation in changing contexts, enabling the easy trespass of different spheres of thinking and help the students to grasp what the contemporary world is about. Postmodern philosophical didactics reflects one of the main features of contemporary culture - its turn towards visual culture. As Duoblienè writes citing Neil Postman and Marshall McLuhan, the contemporary content of upbringing has to correspond to the contemporary world students are living in. The technologies of this world allow them access to information and to create different structure of thinking, which McLuhan names 'mosaic' (Duoblienè 2011: 10). Postmodern philosophical didactics trains the ability to think upon the world as an expression of different contexts; on the other hand, it gives the principle uniting multiplicity - the world as a secret (Jacques Derrida) and the world as becoming (Gilles Deleuze). The secret and the becoming are not metaphysical and ontological concepts but the limits towards which all the discourses converge. Neither philosophy, no morality or religion has access to this secret. "Somehow," writes Derrida, "this secret that we speak of but are unable to say is, paradoxically, like good sense in Descartes, the best-shared thing in the world; but it is the sharing of what is not shared: we know in common that we have nothing in common. There may be unlimited consensus on the subject, but the consensus is of no use, since it is a consensus on the fact that the singular is singular, that the other is other, that tout autre est tout autre" (Derrida Ferraris 2002: 59). All discourses (philosophical, literary, theological, etc. ) are created as a response to this secret. Postmodern didactics is not looking for one privileged narrative, as an authority in comparison with the 'smaller' narratives. Thus the student acquires the status of the creator of any little narrative. The student is encouraged to create his own interpretation on philosophical insights by writing philosophical essays. The orientation of philosophical didactics towards text encourages the erudition 
of students and enlarges their capacities for creative writing, providing them with an intellectual background.

On the other hand, mainly in the framework of such a didactics, the possibility of the meeting between philosophical thinking and existential therapy arises. The aspects that at first seem unimportant and were considered in modern culture as marginal, from the post-modern point of view receive their own value. The criteria and hierarchy giving the more or less value to different phenomena of culture had disappeared for the reason that there is no centre as a point of departure for evaluation. For this reason, the unique student experience has its own independent value. Post-modern thinking does not discriminate as unimportant marginal groups those who lead alternative styles of living, the sexual and ethnic minorities. To George W. F. Hegel's European orientation, the post-modern approach opposes the equality of ethnic groups and civilizations rather distant from the formal world centre as Europe. As Linda Hutcheon notices, "postmodern art is always aware of difference, difference within any grouping too, difference defined by contextualization and positioning in relation to plural ones" (Hutcheon, 2000: 67). For this reason, post-modern philosophical didactics encourages students to trust in her/his own different experience and respect the other's unique difference.

Mainly the tolerance for this difference allows philosophical didactics to use a contemporary method of education the case study. One on the branches of case studies is the writing of philosophical essays.

\section{Creative Thinking and the Multiplicity of Ethical Experience in Post-modern Philosophical Ethics}

Modern philosophical ethics has a tendency to search for one concept as a priority (for John S. Mill it was happiness, for Immanuel Kant, duty), but post-modern philosophical ethics is based on the supposition that no one single concept can represent the variety and multiplicity of moral experience. This aspect is noticed even by analytic philosophical ethics. The British philosopher Bernard Williams in the book Ethics and the Limits of Philosophy (1993) notices: "If there is such a thing as the truth about the subject matter of ethics - the truth, we might say, about the ethical - why is there any expectation that it should be simple? In particular, why should it be conceptually simple, using only one or two ethical concepts, such as duty or good state of affairs, rather than many? Perhaps we need as many concepts to describe it as we find we need, and no fewer" (Williams 1993: 17).

Following a similar presumption, the Reader of Philosophical Ethics for Forms 11-12 was prepared by Jūrate Baranova $(1998,1999,2001)$. The course book is structured through the History of Concepts - Wisdom, Forgiveness, Duty, Suffering, Meaning of Life, Suicide, Responsibility, Freedom, Happiness, Love, Jealousy and Hatred, Woman and Man, Children and Parents, Friendship, and Loneliness. Each topic is structured through the change of the concept from Antiquity to the Philosophy of the twentieth century, keeping in mind that this number of concepts is arbitrary selected, and that the list could and should be enlarged by the students' own reflections upon their own moral experiences when creating new concepts and their own narratives. Currently, this textbook is being renewed and transformed into two new books: Me and You. Form 10 and Meaning and Freedom. Forms 11-12.

The other step is the deconstruction of concepts as was suggested in Jacques Derrida's Politics of Friendship (1997). In this book Derrida reflects upon the concept of friendship from a different point of view. Starting from Aristotle's remark "O, my friends, there is no friend", quoted by Michel de Montaigne and Friedrich Nietzsche, Derrida by paradox of the phrase (one side of the sentence has plural friends, the other side has zero friends) reveals the different possible contradictions incorporated into the phenomenon of friendship. Reading Cicero, Seneca, Aristotle's ethics, philosophical philanthropy in Immanuel Kant's ethics, Friedrich Nietzsche's Thus Spoke Zarathustra, the works on the problem of Other in Emmanuel Levinas, and the opposition of friend and enemy in Carl Schmitt's political philosophy, Derrida asks questions which enlarge the understanding of the complexity of ethical experience. The point that Derrida brings to the initial paradox is that there is less friendship the more friends there are. Confronting Aristotle and Cicero, Derrida reveals that the logic of Aristotle's position is that the fewer the friends, the more the friendship, so that if I am my only friend that is the best friendship as there is no friend. The logic of Cicero's position is that I am my own best friend, because I am the best double of myself. The other questions raised by Derrida are: what is the connection between friendship and love, friendship and time, friendship and death, how is possible selectivity and universality in friendship? In this process of deconstruction, Derrida questions not friendship or morality, but the reduction of the complex phenomenon on morality to abstract concepts and the supposition that these clear concepts are able to represent the multiplicity of ethical experience, which is more close to the secret than to the concept. "Il y a là du secret", Derrida wrote (Derrida 1993: 57). "Un geste " d'amitié » ou " de politesse» ne serait ni amical ni poli s'il obéissait purement et simplement à une règle rituelle", he states in Passions (Derrida, 1993: 21): Instead of the ethics of rituals, principles and imperatives, he suggests the new ethics of deconstruction, based on non-decision (l'inassurance) and inexhaustible possibilities. This ethics avoids the classical clash between fact ("is") and norm ("ought") for the reason that the statement of fact "there is" and imperative of norm "ought to be" is changed to the word "maybe" («comme »). The acknowledgement that there is no "duty" as a 
thing in itself or that there is no responsibility as a thing in itself does not mean that the discourse about the polysemantic of these concepts does not provoke new reflections on moral experience. The ability of the students is to raise open questions and see the world as a permanent becoming of new questions.

Following similar suppositions, the other course-book Philosophy for forms 11-12 was also prepared and published by Jūrate Baranova and Tomas Sodeika in 2002. This textbook interweaves texts and images from philosophy, psychology, literature, paintings and movies. The textbook was republished as two new books: Me and It. Forms 10-11 and Philosophy: Man. Form 12. As noticed by Darius Klibavičius (a philosophy teacher at a Jesuit gymnasium in Kaunas who for years used the textbook in lessons with students with good result, as his students participated not only in the national, but also international philosophy Olympiads with honorable mention awards and in the IPO 2014 received bronze medal), there is no common "bookish" truths in this textbook, and for this reason the teacher is obliged to become an active co-author of the textbook. The textbook trains the capacities of interpretive reading with the usage of the meditation of the written text. The meditation method is the input of Tomas Sodeika into philosophical didactics. "In discussion and disputes inevitably we are arguing and the problem becomes split up into parts in order to become clear to all the parts of discussion, but in meditation we do not discuss pro and contra, and the criteria of truthfulness are suspended, but the personal experience unites the meaning of pronounced word and in this inactivity brings it closer to students' life" (Klibavičius, 2003: 53). As Zenonas Norkus noticed, in writing a review on this textbook, "the uniting of philosophy, poetry, prose and visual art under one cover is an exact response to the Rorty's ideas and makes the book perhaps the most distinct phenomenon of post-modern literature in contemporary Lithuanian philosophical discourse" (Norkus, 2003: 186). But post-modern suppositions for training creative thinking in this textbook, as well as in the previously discussed one, are combined with a modernist principle of logical sequence. Klibavičius stated that, "although there is a large amount of texts, they are short and different; it is possible to group them very strictly according to topics. They are tastefully grouped, so it is possible to select them according to one's own opinion regardless of the right way previously stated for primacy. Here, as it suits to philosophical treatise, one can find more references, hints and encouragements than answers" (Klibavičius 2003: 54)

\section{The Interdisciplinary Approach and the Openness of Thinking in Post-modern Philosophical Didactics}

One of the main features of post-modern philosophical didactics is that it focuses on the interdisciplinary openness of thinking. The methodological approach to the interdisciplinary aspect of philosophical didactics is Gilles Deleuze and Felix Guattari's experimental thinking. In the book What is philosophy? (Qu'est-ce que la philosophie? 1991) they write: "What defines thought in its three great forms - art, science, and philosophy - is always confronting chaos, laying out a plane, throwing a plane over chaos. But philosophy wants to save the infinite by giving it consistency: it lays out a plane of immanence that, through the action of conceptual personage, takes events or consistent concepts to infinity. Science, on the other hand, relinquishes the infinite in order to gain reference: it lays out a plane of simply undefined coordinates that each time, through the action of partial observers, defines states of affairs, functions, or referential propositions. Art wants to create the finite that restores the infinite: it lays out a plane of composition that, in turn, through the action of aesthetic figures, bears monuments or composite sensations" (Deleuze Guattari 1994: 197). Every path they consider as unique. Three forms of thought could be seen as parallels and intersections, but they do not coincide and are not seen as synthesis. Deleuze and Guattari write: "Philosophy proceeds by sentences, but it is not always propositions that are extracted from sentences in general. At present we are relying only on a very general hypothesis: from sentences or their equivalent, philosophy extracts concepts (which must not be confused with general or abstract ideas), whereas science extracts prospects (propositions that must not be confused with judgments), and art extracts percepts and affects (which must not be confused with perceptions or feelings). In each case language is tested and used in incomparable ways-but in ways that do not define the difference between disciplines without also constituting their perpetual interbreeding" (Deleuze Guattari 1994: 24).

Philosophical passages of the abovementioned textbook Reader of Philosophical Ethics interweave poetry and prose with literature, including passages from the New Testament, and works of psychologists (Sigmund Freud, Erich Fromm). The topic starts with poetry, initiating an interpretative attitude, and finishes with the prose passage which allows the reader to find a certain relationship with the expression of this problem in everyday life. For example, "Jealousy and Hate" begins with Charles Baudelaire's poem "Reversibility. " It is followed by excerpts from philosophers' (Socrates, Aristotle, Plutarch, Francis Bacon, Bernard Mandeville, Claude Adrien Helvetius) on the meaning of these two concepts, then psychologists' (Freud's, Fromm's) conceptions are discussed. Finally, the phenomenon is revealed by writer's August Strindberg's excerpt from his novel The Confession of a Fool and Andre Maurois' insights about the ability of love to transcend the personal ego in his novel The Climates of Love. Each topic is composed by the same interdisciplinary 
interweaving of philosophy, science, and art, not only in this textbook, but also in the abovementioned Philosophy for forms 11-12.

All parts of the textbook are united by the means of a number of the questions which encourage both critical and creative thinking but all these extracts are united into one single consequent narrative. On the other hand, the boundaries of different spheres of culture are dissolved and the methods of post-modern didactics are taken into play. So it happens that this approach unites the modern and post-modern aspects of philosophical didactics in one single project.

Deleuze and Guattari say that the plane of composition of literature and the plane of the immanence of philosophy are able to penetrate into each other in such a manner that a part of one could be composed from the parts of the other. But they never create a synthesis. These parts nevertheless remain heterogeneous. The thinker is able to modify the thinking, include new images of thinking, and establish the new plane of immanence. The creation of concepts could be replaced by insights from poetry, novels, painting or musical works. But the movement in the opposite direction is also possible. Mainly in this "in-between", in this clash of two modes of thinking - between philosophy and literature - the new expression of thought emerges.

\section{The Interdisciplinary Approach and Creative Thinking: Philosophy and Visual Arts}

Post-modern philosophical didactics open the possibility for intersections not only between thought and image or concept and metaphor, but also the intersection of these two segments with the visual image as well. How can it be possible to use, for example, the paintings of Belgian surrealist René Magritte (1898-1967) in encouraging creativeness of philosophical thought? Magritte proposed an "optimistic" version of surrealism, based not on the unconsciousness or dreams but on the unexpected overturning of reality. His paintings are examples of plausible inversions of formal logic and ordinary meaning, leading in each case to a paradox. Magritte once said: "The sense of exactitude is no obstacle to a pleasure in in-exactitude". Or again: "The language of authenticity 'gives the word' to words by making them say what they never said" (Meuris 1994: 123). Magritte in his painting posted the question of whether words really do have the meaning usually attributed to them in everyday usage. In the picture The Key to Dreams it is clearly recognizable that you are confronted with definitions which are, on the face of it, inappropriate. There is then clearly a desire to use pictures as a means of confusion where the received definitions are concerned. Magritte's pictures were the subject of numerous philosophical interpretations, especially by Michel Foucault. Following his essay Les mots et les choses, he wrote another entitled Ceci n'est pas une pipe (1973). Magritte responded to it with two letters. It is quite clear that the most obvious, and simplest, explanation lies in the observation that the picture of a pipe is nothing other than the representation of a smoker's accessory,and cannot itself be used for smoking. "But equally it throws the gates wide open to paradox an aporia (aporia being "a difficulty arising from an awareness of incompatible views on the same theoretic matter"). For the viewer of this painting, the object represented clearly is a pipe, no doubt about it. And why should this pipe not be a pipe? For the same reason that the word "dog" doesn't bark, as William James has observed <..." (Meuris 1993: 129).

Being a painter, Magritte used to experiment with the established order of people's limited possibilities at the same time as if asking the main philosophical question stated by Kant "How would it be if...?" How would it be if the painter were able to paint the other person not only in the picture, but also in reality as well? (Attempting the Impossible, 1928). How would it be if the person, instead of only having two hands, were able to have four? (The Magician, 1952). How would it be if one's head would shine as if it were the sun? (The Pleasure Principle: Portrait of Edwards James, 1937). How would it be if one were able to observe the world not as one usually does, but with eyes in the back of the head? (The Glass House, 1939). How would it be if in lying near the sea one were to suddenly feel that a part of one's body is going to be a part of the fish? (Collective invention, 1934). How would it be if one's image in the mirror were reflected not as a face but as the back of one's head? (Reproduction Prohibited: Portrait of Edward James, 1937). The intellectual intrigue encoded into the plot of the picture could become an equivalent to the philosophical question and by this turn to become a visual possible means for encouraging flexible abstract thinking. When interpreting the pictures as puzzles created by Magritte in such a manner, it is possible to remember the thought expressed by Derrida in one of his interviews, when he said that it is important not only the events that happen to us but the events that never happened as well. Magritte it seems would have added: what are important also are the events that never could have had happen at all. By critically analyzing and reflecting upon this impossibility, students develop the ability to more deeply understand the aspects of possibility as such and to grasp the features of the real world.

How is it possible to include moving pictures as movies into the philosophy teaching curriculum? Since 2004 the program "Cinema in my school" provided in the Lithuanian schools has emphasized the cinema art more as a technological expression of moving image.

From the perspectives of post-modern didactics, cinema can be included into the curriculum as a means to training 
the critical as well as creative aspects of thought. Sometimes the movies could be used as an illustration of philosopher's lives, as, for example, The Last Days of Immanuel Kant by Philippe Collin and André Scala (1993), Nietzsche's Days in Turin (2001), by Júlio Bressane Les Amants Du Flore (2006) by Duran Cohen; or Sartre, l'âge des passions (2006) by Claude Goretta. Sometimes movies could be used as a visual illustration of certain philosophical novels such as Albert Camus's Stranger (1967), adapted to cinema by Lucino Visconti or Jean Paul Sartre's play The Proud and the Beautiful (1953) by Yves Allégret, No Exit (1953) by Jacqueline Audry or The Condemned of Altona (1962) by Vittorio De Sica. One of the productive usages is the case when a fictional movie or documentary were created as an encounter not only with the philosopher's life, but his conception as well, as, for example, what happened in Wittgenstein (1993) by Derek Jarman, or the documentary Derrida (2002) created by Kirkby Dick and Amy Ziering Kofman.

But does cinema have something to do with encouraging critical and creative thinking? Cinema in philosophical didactics can be used as a provocation for thought experiment.

Some philosophers state that movies are not an explicit illustration of philosophy, but they could encourage us to philosophize by suggesting thought experiments in the same manner as Plato suggested thought experiments in the allegory of the Rock. So it is possible to use the movie The Matrix by the Wachowski brothers as a possible thought experiment in comparison with Descartes skepticism. Goodenough notices: "This set of dark science-fiction fantasies provides a graphic illustration of a number of philosophical issues. Our hero, $\mathrm{NeO}$, is awakened from his everyday life to discover that that life was in fact a computer programme; in reality, his body - together with those of almost all other human beings in the world - was being kept unconscious by the machines that have now taken over the world. The Matrix is a shared life-programme generated by the machines and fed to these bodies, giving them a consistent dream that they take to be everyday life. Such a film appeals to some long-standing philosophical problems; to the difference between appearance and reality, to questions of solipsism, of the nature of dreaming, and so on. It illustrates certain moves in Descartes' methodological skepticism in the Meditations, adapts Putnam's brain-in-a-vat case, and relates to Nozick's experience-machine" (Goodenough 2005: 2).

Jonas Dagys and Nerijus Milerius, Lithuanian philosophers from Vilnius University, created twelve videos titled Classical and Contemporary Issues/Problems of Philosophy (Klasikinės ir šiuolaikinés filosofijos problemos), which could be used in teaching philosophy as an interdisciplinary subject for the reason that in this project philosophers, anesthetists, physicists, film directors, etc. , are discussing from their own perspectives the problems of existence, nature, goodness, beauty, language, daily life, time, freedom, consciousness, justice, truth and faith.

A turn in Modern Western philosophy towards the visualization made an impact on the didactic attitude of the Department of Philosophy at the Lithuanian University of Educational Sciences as well. References to films are introduced next to art reproductions. For example, in analyzing the topics "Person and Body," the film The Double Life of Veronique (La double vie de Véronique), directed by Krzystof Kieslowski, is suggested for consideration of the problem of personal identity from the open perspective of philosophers, writers and film makers.

What is the mission of cinema in comparison to other arts in training the students' thought experience? Russian director Sergej Eisenstein would had have said: in the path from the image to thought there is a shock or vibration, which must give rise to a thought in a thought; afterwards there is a movement from thought to image and some kind of internal monologue (rather than in a dream) capable of giving us a shock again. Antonin Artaud, although differently than Eisenstein, considers that what cinema advances is not the power of thought but its "impower", nevertheless considers the thought its main purpose. Deleuze, as if following Jean-Louis Schefer's idea, expressed in the book Common man in cinema (L'homme ordinaire du cinema): "it is suspension of the world, rather than movement, which gives the visible to thought, not as its object, but as an act which is constantly arising and being revealed in thought : 'no that it is here a matter of thought become visible, the visible is affected and irremediably infected by the initial incoherence in thought, this inchoate quality" (Deleuze 1985: 161-162). Deleuze agrees with them say, "it is true that bad cinema (and sometimes good) limits itself to a dream state or imaginary participation. But the essence of cinema - which is not the majority of films - has thought as its higher purpose, nothing but thought and its functioning" (Deleuze 1985: 163).

\section{Conclusion}

Critical and creative thinking are the aims of different sorts of philosophical didactics. Modern philosophical didactics emphasizes logical aspects of critical thinking and post-modernism uses the interdisciplinary and inter-textual approach to encourage creative thinking. Our conclusion is that these two didactics could work not necessarily in opposition but as complementary to each other for the following reasons:

- Both modern and post-modern philosophical didactics are orientated to one goal - to the training of the becoming of thought; 
- Both modern and post-modern didactics emphasize the training of student reflectivity as a process and not a definite goal;

- Both modern and post-modern didactics are inclined to train cosmopolitan and civic society values;

Final conclusion: both modern and post-modern didactics differ by the utilized methods but not in the understanding of the content of education. Their possible coordination would have created a more poly-semantic field for the possible training of students' thinking.

\section{References}

Aškinytè, R. Degėsys, L. (2006) Etika kaip loginio mastymo teorija ir praktika Vadovèlis aukštuju mokyklu studentams. (Ethics as a Theory and Practice of Logical Thinking. A textbook for the college students). II-asis pataisytas ir papildytas leidimas. Vilnius: VPU leidykla.

Baranova, J. (2002) Etika: filosofija kaip praktika. Mokytojo knyga (Ethics: Philosophy as a Practice. A Teacher's Book). Vilnius: Tyto alba.

Baranova, J. (2004a) Filosofinė etika: Aš ir Tu. Vadovèlis 10 kl. (Philosophical Ethics: Me and You. A textbook for 10 form). Vilnius: Alma litera.

Baranova, J. (2004b) Filosofinè etika: prasmè ir laisvè. Vadovèlis 11-12 kl. (Philosophical Ethics: Meaning and Freedom. A textbook for 11-12 forms). Vilnius: Alma littera.

Baranova, J. Sodeika, T. (2007a) Filosofinè etika : Aš ir Tai. Vadovèlis 11 kl. (Philosophical Ethics: Me and That. A Texbook for 11 form). Vilnius: Tyto alba.

Baranova, J. Sodeika, T. (2007b) Filosofija : Žmogus. Vadovėlis 12 kl. (Philosophy: Man. A texbook for 12 form). Vilnius: Tyto alba.

Baranova, J. (2009) Filosofinès abejonès dèl mąstymo ir jausmu priešpriešos moralinio ugdymo procese (Philosophical Doubts on the Controversy Between Reason and Feeling in the Process of Moral Upbringing). Acta Paedagogica Vilnensis, no. 22, pp. 25-36.

Baranova, J. (2012). Kritinis mąstymas ir retorinè iškalbos ugdymas (The Role of Critical Thinking and Rhetorics in Upbringing). Acta Paedagogica Vilnensia, no. 28, pp. 96-106.

Baranova, J. (2012) Kino menas ir filosofinė edukacija: contra ir pro (Cinema and Philosophical Education: contra and pro). Žmogus ir žodis, no. 4, pp. 31-43.

Degèsys, L. (2011) Education as liberation of the self: principles and concepts of learning and teaching in the Pestalozzi Programme. In Teacher Education for Change. The theory behind The Council of Europe Pestalozzi Programme. Strasbourg Cedex: Council of Europe Publishing, pp. 47-59.

Degèsys, L. (2005) Ethics as Theory and Practice of Logical Thinking. In Educational Systems Development as Development of Human Being. Frankfurt am Main: Peter Lang. Europaisher Verlag der Wisseschaften, 2005, pp. 89-97.

Degėsys, L. (2006) La quotidianità come metafisica. In TransEuropaExpress. L'Europa alla prova del consenso. Roma: Donzelli Editore, 2006.

Deleuze, G. (1985) Cinéma 2. l'Image-temps. Paris: Les éditions de minuit.

Deleuze, G. , Guattari, F. (1994) What is Philosophy? New York: Columbia University Press.

Derrida, J. , Ferrari M. (2002) A Taste for the Secret. Cambridge, UK, Oxford UK, Malden USA: Polity Press.

Derrida, J. (1997) Passions. Paris: éditions Galilée.

Derrida, J. (2007) Jacques Derrida. Basic Writings. Ed. B. Stocker. London and New York: Routledge.

Duoblienè, L. (2006) Šiuolaikinè ugdymo filosofija: refleksijos ir dialogo link. (Contemporary Philosophy of Education: Towards Reflection and Dialogue). Vilnius: Tyto alba, 2006.

Duobliené, L. (2011) Ideologizuotos švietimo kaitos teritorijos. (Ideological Territories of Educational Change ). Vilnius: Vilniaus universiteto leidykla.

Duoblienè, L. (2000) Mąstymo ugdymas mokant filosofijos gimnazijoje (Teaching Phylosophy in Secondary School: Formation of Thinking. ). Daktaro disertacijos rankraštis. VU.

Goodenough J. (2005) Introduction I: A Philosopher Goes to the Cinema. In Film as Philosophy. Essyas in Cinema After Wittgenstein and Cavell. Houndmills and New York: Palgrave Macmillan, pp. 1-28.

Filosofinès etikos chrestomatija, XI-XII kl. (Anthology of Philosophical Ethics for 11-12 forms) Sud. J. Baranova. Vilnius: Alma littera, 2001.

Hutcheon, L. (2000) A Poetics of Postmodern History, Theory, Fiction. New York, London: Routledge, 2000.

Klibavičius, D. (2003) Kaip skaityti filosofijos vadovèli XI-XII klasėms? (How to Read the Texbook of Philosophy for 11 and 12 forms?). Žmogus ir žodis. 2003, no. 4, pp. 52-55.

Norkus, Z. (2003) Naujos knygos besimokantiems filosofuoti (New Books for Learners to Philosophize). Problemos, t. 64, pp. $182-187$.

Popper, K. R. (1992) The Logic of Scientific. Discovery. London and New York: Routledge.

Sodeika, T. Baranova, J. (2002) Filosofija. Vadovèlis 11-12 kl. (Philosophy) Vilnius: Tyto alba.

Williams, B. (1993) Ethics and the Limits of Philosophy. Glasgow: Fontana press. 